\title{
PEMBENTUKAN KARAKTER CALON PENGURUS ORGANISASI SANTRI BINA UMAT (OSB)
}

\author{
Marwah Rusydiana \\ Universitas Islam Negeri Sunan Kalijaga \\ marwah.rusydiana93@gmail.com
}

\begin{abstract}
Abstrak
Penelitian ini bertujuan untuk mengetahui metode yang digunakan dalam pembentukan karakter peserta didik yang akan menjadi calon pengurus OSB masa bhakti 2018-2019 serta karakter yang harus ada pada diri pengurus OSB itu sendiri. Penelitian ini merupakan jenis penelitian lapangan yang bersifat deskriptif kualitatif. Subjek dalam penelitian ini adalah pembimbing OSB, wali kelas, dan lima peserta didik kelas 11 . Pengumpulan data dengan menggunakan teknik observasi, wawancara, dan dokumentasi. Untuk menguji keabsahan data dalam penelitian ini dengan menggunakan teknik triangulasi. Hasil penelitian menunjukkan Karakter yang dibentuk dalam menyiapkan calon Pengurus OSB yaitu religius, jujur, toleransi, disiplin, kerja keras, mandiri, demokratis, cinta tanah air, bersahabat, cinta damai, peduli lingkungan, peduli sosial, dan tanggungjawab. Metode yang digunakan dalam membentuk karakter calaon pengurus OSB yaitu: (1) Metode ceramah, Metode ini dilakukan dalam setiap kegitatan yang dilakukan oleh pembimbing ataupun wali kelas; (2) Metode Diskusi, metode ini dilakukan ketika sedang ada kumpul dengan pengurus OSB ataupun ketika mendampingi rapat pengurus OSB; (3) metode Pemberian tugas (resitasi), Pengurus OSB diberikan tugas sesuai dengan bagiannya; dan (4) Metode Pembiasaan, Pengurus OSB dilatih untuk disiplin, memutuskan untuk mengadakan kegiatan dalam rapat atau dengan musyawarah mufakat.
\end{abstract}

Kata Kunci: pembentukan karakter, calon pengurus OSB. 


\begin{abstract}
This study aims to find out the methods used in the formation of character of students who will become candidates for the management of OSB 2018-2019 and the character that must be present in the OSB management itself. This research is a kind of qualitative descriptive field research. The subjects in this study were OSB supervisors, homeroom teachers, and five 11th grade students. Data collection using observation, interview, and documentation techniques. To test the validity of the data in this study by using triangulation techniques. The results of the study show that the Character was formed in preparing candidates for OSB Management, namely religious, honest, tolerant, disciplined, hard work, independent, democratic, loving the country, friendly, peaceloving, caring for the environment, social care, and responsibility. The method used in forming the character of the OSB management calaon are: (1) The lecture method, this method is carried out in every activity carried out by the supervisor or homeroom teacher; (2) Discussion Method, this method is carried out when there is a gathering with the OSB management or when accompanying the OSB board meeting; (3) method of assigning tasks (recitation), OSB Management is given assignments in accordance with their parts; and (4) Habitual Method, OSB Management is trained in discipline, decides to hold activities in meetings or with consensus meetings.
\end{abstract}

Keyword: the formation of character, candidates for the organization OSB

\title{
Pendahuluan
}

Pendidikan merupakan urusan penting dalam kehidupan manusia. Tanpa pendidikan kehidupan seseorang tidak akan berkembang dengan baik. Pendidikan bukan hanya dalam kecerdasan intelektual saja namun dalam karakter individu juga harus diperhatikan. Karakter adalah kumpulan tata nilai yang menuju pada suatu sistem, yang melandasi pemikiran, sikap, dan perilaku yang ditampilkan (muchlas samani dan hariyanto, 2011). Tujuan pendidikan karakter pada dasarnya adalah mendorong 
lahirnya anak-anak yang baik (insan kamil). Serta kesuksesan seseorang tidak ditentukan semata-mata oleh pengetahuan dan kemampuan teknis (hard skill) saja, akan tetapi lebih pada kemampuan mengelola diri dan orang lain (soft skill) (Ali Ibrahim Akbar, 2003). Hal ini mengisyaratkan bahwa mutu Pendidikan Karakter peserta didik sangat penting untuk ditingkatkan.

Kemajuan zaman yang terjadi saat ini, yang semula dipandang akan memudahkan pekerjaan manusia, kenyataannya juga menimbulkan keresahan dan ketakutan baru bagi manusia, yaitu kesepian dan keterasingan baru, yang ditandai dengan lunturnya rasa solidaritas, kebersamaan, dan silaturrahim.( Moh. Haitami dan Syamsul Kurniawan, 2012).

Alasan-alasan kemerosotan moral, dekadensi kemanusiaan yang sesungguhnya terjadi tidak hanya dalam generasi muda, tetapi telah menjadi ciri khas abad kita.keadaan ini seharusnya membuat kita perlu mempertimbangkan kembali bagaimana lingkungan keluarga, sekolah, dan masyarakat sehingga mampu menyumbangkan perannya bagi perbaikan karakter. Diakui, persoalan karakter atau moral memang tidak sepenuhnya terabaikan. Akan tetapi, dengan fakta-fakta kemerosotan karakter pada sekitar kita menunjukkan bahwa ada kegagalan pada pendidikan yang diterapkan dilingkungan keluarga, sekolah,dan masyarakat dalam hal menumbuhkan remaja dan anak-anak yang berkarakter dan berakhlak mulia (Syamsul Kurniawan, 2012).

Thomas Lickona mengungkapkan bahwa ada sepuluh tandatanda zaman yang harus diwaspadai karena jika tanda-tanda ini sudah ada, berarti sebuah bangsa sedang menuju jurang kehancuran. Tanda-tanda yang dimaksud adalah Meningkatnya kekerasan di kalangan remaja, Penggunaan bahasa dan kata-kata yang memburuk, Pengaruh peer-group yang kuat dalam tindak 
JIPSINDO No. 1, Volume 6, Maret 2019

kekerasan, Meningkatnya perilaku merusak diri, seperti penggunan narkoba, alkohol, dan seks bebas, Semakin kaburnya pedoman moral baik dan buruk, Menurunnya etos kerja, Semakin rendahnya rasa hormat kepada orang tua dan guru, Rendahnya rasa tanggungjawab individu dan warga Negara, Membudayanya ketidak jujuran, dan Adanya rasa saling curiga dan kebencian di antara sesama.

Kualitas manusia bukan hanya ditentukan oleh kecerdasan dan keahlian.tidak cukup manusia dinilai dari keterampilan, dan profesionalitasnya saja. Manusia yang hanya dipacu dalam kecerdasan bukan indahkan perilaku, siap-siap lahir serigala baru. Manusia yang hanya dididik ambisinya, jadilah manusia yang teramat egois dan sombong. Pribadi yang dilatih hanya untuk memenangkan persaingan, tidak akan memiliki nurani dan tidak mau mengetahui dan tidak mau mengakui hak orang lain. Oleh karena itu, sesungguhnya kualitas manusia ditentukan oleh $2 \mathrm{~K}$, yakni kompetensi dan karakter (Replubika, 2011).

Pembentukan karakter juga merupakan salah satu tujuan pendidikan nasional. Pasal I Undang-undang Sistem Pendidikan Nasional tahun 2003 menyebutkan bahwa diantara tujuan pendidikan nasional adalah mengembangkan potensi peserta didik untuk mempunyai kecerdasan, kepribadian, dan akhlak yang mulia. Amanah Undang-undang Sistem Pendidikan Nasional tahun 2003ini bermaksud agar pendidikan tidak hanya membentuk insan insan Indonesia yang crdas, tetapi juga berkepribadian atau berkarakter sehingga nantinya akan lahir generasi bangsa yang tumbuh berkembang dengan karakter yang bernapas nilai-nilai luhur bangsa serta agama.

Karakter yang positif atau mulia yang dimiliki remaja dan anak-anak kelak akan mengangkat status derajatnya. Kemuliaan 
Marwah Rusydiana

seseorang terletak pada karakternya. Karakter begitu penting karena dengan karakter yang baik membuat seorang tahan dan tabah dalam menghadapi cobaan dan data menjalani hidup dengan sempurna. Kestabilan hidup seseorang amatlah tergantung pada karakter. Karakter membuat indiviu menjadi matang, bertanggung jawab, dan produktif.

Pembentukan karakter tentunya sangat penting untuk diterapkan kepada semua siswa, khususnya siswa yang menjadi pengurus OSIS (Organisasi Siswa Intra Sekolah) yang mana siswa tersebut diharapkan mempunyai karakter yang bagus dan mampu melaksanakan tugas kepengurusan dengan baik. Dalam surat keputusan direktur jenderal pendidikan dasar dan menengah nomor 226/C/Kep/0/1992 disebutkan bahwa organisasi kesiswaan di sekolah adalah OSIS yang merupakan satu-satunya organisasi intra yang berada di setiap sekolah/madrasah menengah (SLTP/SLTA) dan merupakan organisasi yang sah di sekolah dan tidak mempunyai hubungan organisatoris dengan OSIS di sekolah lain, yang dipimpin oleh pembina OSIS dalam setiap melaksanakan kegiatan yang diadakan oleh pengurus OSIS.

Masalah tersebut juga di alami pada SMA IT Bina Umat yang mana sopan-santun siswa atau santri zaman dahulu dengan sekarang sangat berbeda, saat ini terjadi penurunan. Organisasi Bina Umat merupakan organisasi intra sekolah seperti organisasi yang ada di sekolah lainnya. Organisasi ini memegang peranan penting dalam kegiatan sekolah dan kegiatan pondok yang mana selain guru, OSB juga bertanggungjawab dalam setiap kegiatan. Pengurus OSB yaitu semua peserta didik kelas 11 SMA IT Bina Umat, itu berbeda dengan sekolah lain yang mana pengurus OSIS adalah siswa pilihan atau dipilih dan tidak semua menjadi OSIS. Dari berbagai karakter yang berbeda antara satu dengan yang 
lainnya muncullah permasalahan, permasalahan dalam hal persepsi yang berbeda, kerjasama yang belum terbangun, perselisihan antara satu dan lainnya, dan lain sebagainya. Dari latar belakang tersebut penulis melakukan penelitian yang bertujuan untuk mengetahui Metode Pembentukan Karakter Calon Pengurus Organisasi Santri Bina Umat (OSB) masa bhakti 20182019 serta karakter yang harus ada pada diri pengurus OSB itu sendiri.

\section{Pembentukan Karakter}

Dalam Kamus Besar Bahasa Indonesia, pembentukan adalah proses, perbuatan, cara membentuk. Sedangkan Menurut Kamus Besar Bahasa Indonesia, karakter adalah sifat-sifat kejiwaan,akhlak, atau budi pekerti yangmembedakan seseorang dari yang lain. Istilah karakter dalam bahasa inggris character, berasal dari istilah Yunani character dari kata charassein yang berarti membuat tajam atau membuat dalam. karakter juga dapat berarti mengukir. Sifat utama ukiran adalah melekat kuat diatas benda yang diukir. Karena itu, karakter adalah ciri khas seseorang dan karakter tidak dapat dilepaskan dari konteks sosial budaya karena karakter terbentuk dalam lingkungan sosial budaya tertentu.

Karakter mengacu pada serangkaian sikap (attitudes), perilaku (behavior), motivasi (motivations), dan keterampilan (skills). Menurut Zubaedi, karakter meliputi sikap seperti keinginan untuk melakukan hal yang terbaik, kapasitas intelektual seperti kritisdan alasan moral, perilaku seperti jujur dan bertanggung jawab, mempertahankan prinsip-prinsip moral dalamsituasi penuh ketidakadilan, kecakapaninterpersonal dan emosional yang memungkinkan seseorang berinteraksi secara 
Marwah Rusydiana

efektif dalam berbagai keadaan, dan komitmen untuk berkontribusi dengan komunitas dan masyarakatnya. Griek yang dikuti Zubaedi, merumuskan definisi karakter sebagai paduan dari segala tabiat manusia yang bersifat tetap sehingga menjadi tanda yang khusus untuk membedakan orang yang satu dengan yang lain. Batasan ini menunjukkan bahwa karakter sebagaiidentitas yang dimiliki seseorang yang bersifat menetap sehingga seseorang atau sesuatu itu berbeda dari yang lain.

Dengan pengertian di atas dapat dikatakan bahwa membangun karakter (character building) adalah proses mengukir atau memahat jiwa sedemikian rupa, sehingga "berbentuk" unik, menarik, dan berbeda atau dapat dibedakan dengan orang lain. Ibarat dalam sebuah huruf dalam alphabet yang tak pernah sama antara yang satu dengan yang lain, demikianlah orang-orang yang berkarakter dapat dibedakan satu dengan yang lainnya (termasuk dengan yang tidak/belum berkarakter "berkarakter" tercela) (Zaim Elmubarok, 2008).

Dari beberapa pengertian diatas, pembentukan karakter adalah proses atau cara untuk merubah sifat, atau watak kearah yang lebih baik. Dengan adanya kegiatan pembentukan karakter, sangat membantu siswa untuk membentuk karakter religius, jujur, disiplin, serta bertanggung jawab. Tercapainya suatu kegiatan pembentukan karakter siswa tergantung dari peran pembina sebagai pembimbing, motivator dan evaluator.

Untuk membentuk karakter seseorang tidaklah mudah, membutuhkan waktu yang lama dan adanya kesadaran dalam diri individu itu sendiri. Untuk membentuk karakter kita harus tau apa yang harus mengetahui komponen yang ada. Komponen karakter yang baik untuk dimiliki dan harus dikembangkan setiap manusia harus memiliki 3 komponen sebagai berikut yaitu 
JIPSINDO No. 1, Volume 6, Maret 2019

pengetahuan moral, perasaan moral dan tindakan moral tidak terpisahkan satu sama lain namun saling mempengaruhi dengan beragam cara. Penilaian moral perasaan moral berpengaruh terhadap perilaku moral, misalnya ketika kita memaafkan dan berbuat baik kepada seseorang yang tadinya membuat kita sangat marah, biasanya kita akan mendapati bahwa pikiran dan perasaan kita terhadap orang tersebut menjadi lebih positif. Secara mikro pengembangan karakter dibagi dalam empat pilar, yakni kegiatan belajar-mengajar di kelas dengan pengintegrasian pada semua mata pelajaran. Untuk membentuk karakter seseorang ada faktor-faktor yang melatarbelakanginya faktor intern dan faktor ekstern.

1. Faktor Intern

a. Insting atau Naluri

Insting adalah suatu sifat yang dapat menumbuhkan perbuatan yang menyampaikan padatujuan dengan berpikir lebih dahulu kearah tujuan itu dan tidak didahului latihan perbuatan itu. Naluri merupakan tabiat yang dibawa sejak lahir yang merupakan suatu pembawaan yang asli.

b. Adat atau kebiasaan

Kebiasaan adalah perbuatan yang selalu diulangulang sehinggamudah untuk dikerjakan.

c. Kehendak atau kemauan

Kemauan ialah kemauan untukmelangsungkan segala ide dan segala yang dimaksud walaudisertai dengan berbagai rintangan dan kesukaan-kesukaran, namun sesekali tidak mau tunduk kepadarintangan-rintangan tersebut.

d. Suara batin atau suara hati 
Marwah Rusydiana

Suara batin berfungsi memperingatkan bahayanya prbuatan buruk dan berusaha untuk mencegahnya, di samping dorongan untuk melakukan perbuatan baik.

e. Keturunan

Keturunan merupakan suatu factor yang data memengaruhi perbuatan manusia.

2. Faktor Ekstern

a. Pendidikan adalah usaha meningkatkandiridalam segala aspeknya.

b. Lingkungan adalah suatu yang melingkungi suatu tubuh yang hidup, seperti tumbuh-tumbuhan,keadaan tanah,udara,dan pergaulan manusia hidup selalu berhubungan dengan manusia lainnya ataualam sekitar. Itulah sebabnya manusia harus bergaul dan dalam pergaulan itu saling mempengaruhiikiran,sifat, dan tingkah laku.

Ada enam pilar penting karakter manusia yang dapat digunakan untuk mengukur dan menilai watak/perilakunya, yaitu respect (penghormatan), responsibility (tanggung jawab), citizenship-civic duty (kesadaran berwarganegaraan), fairness (keadilan), caring (kepedulian dan kemauan berbagi) dan trustworthiness (kepercayaan). Adapun nilai-nilai yang dikembangkan dalam pendidikan budaya dan karakter bangsa yaitu: (1) religious; (2) jujur; (3) toleransi; (4) disiplin; (5) kerja keras; (6) kreatif; (7) mandiri; (8) demokratis; (9)rasa ingin tahu;(10) semangat kebangsaan; (11) cinta tanah air; (12) menghargai prestasi; (13) bersahabat; (14) cinta damai; (15) gemar membaca; (16) peduli lingkungan; (17) peduli sosial; (18) tanggungjawab.( Pupuh Fathurrohman, 2013). 
Untuk membentuk karakter peserta didik, maka dibutuhkan adanya metode yang cocok untuk diterapkan. Metode adalah cara yang teratur dan berfikir baik-baik untuk mencapai (ilmu pengetahuan), cara kerja yang bersistem untuk memudahkan pelaksanaan sesuatu kegiatan guna mencapai tujuan yang ditentukan. Beberapa metode pendidikan yang digunakan dilingkungan sekolah antara lain metode ceramah, Tanya jawab,diskusi, latihan (drill), pemberian tugas (resitasi), cerita, demonstrasi, sosio-drama, dan sebagainya (syamsul kurniawan, 2016).

\section{Metode Penelitian}

Penelitian ini dilakukan di SMAIT Bina Umat Moyudan, Sleman. Dalam penelitian ini, penulis melakukan penelitian menggunakan jenis penelitian lapangan (field research) yang bersifat deskriptif kualitatif. Penelitian kualitatif (qualitatif research) adalah suatu penelitian yang ditujukan untuk mendiskripsikan dan menganalisis fenomena, peristiwa, aktifitas sosial, sikap, kepercayaan, persepsi, pemikiran orang secara individual atau kelompok.

Subjek penelitian adalah orang-orang yang menjadi sumber informasi dan dapat memberikan data sesuai dengan masalah yang akan diteliti. Dalam penelitian ini yang menjadi subjek penelitian adalah wali kelas XI IPA B yaitu Ustadzah Banatul Muflihati, Pembimbing OSB yaitu Ustadzah Sinta Isthofa Haniek, dan 5 pengurus OSB yaitu NH, HFR, AHS, AH, dan LY.

Objek penelitian adalah masalah apa yang hendak diteliti atau masalah penelitian yang disajikan objek penelitian, pembatas yang dipertegas dalam penelitian. Dalam penelitian ini yang menjadi objek penelitian adalah metode pembentukan karakter 
Metode Pembentukan Karakter Calon Pengurus Organisasi Santri Bina Umat (OSB) serta karakter yang harus ada pada diri pengurus OSB itu sendiri masa bhakti 2018-2019.

Dalam penelitian ini penulis menggunakan beberapa metode untuk mengumpulkan data, yang mana dengan hal tersebut diharapkan akan saling melengkapi dan menyempurnakan antara data yang satu dengan yang lainnya. Metode pengumpulan data dalam penelitian ini adalah observasi, wawancara, dan dokumentasi.

Observasi yang digunakan adalah observasi non partisipan, yaitu metode observasi yang dilakukan dengan pengumpulan data, penulis tidak ambil bagian dalam setiap kehidupan obyek yang akan diteliti. Dalam penelitian ini, penulis menggunakan inteview bebas terpimpin yaitu wawancara berdasarkan pertanyaan yang telah dipersiapkan tetapi diserahkan kepada kebijaksanaan interviewer. Metode Dokumentasi yaitu metode pengumpulan data yang ditujukan pada penguraian dan penjelasan apa yang telah lalu melalui sumber dokumen. Dokumen bisa berbentuk tulisan, gambar, atau karya-karya monumental dari seseorang.

Untuk menguji keabsahan data dalam penelitian ini digunakan teknik triangulasi, triangulasi diartikan sebagai teknik pengumpulan data yang bersifat menggabungkan dari berbagai teknik pengumpulan data dan sumber data yang telah ada. Dalam penelitian ini digunakan penulis untuk menguji keabsahan data yang dilakukan dengan menggabungkan dari beberapa metode pengumpulan data untuk mengecek kredibilitas data. Adapun data-data yang dilakukan pengecekan ulang terkait keabsahannya adalah data hasil observasi, dokumentasi, dan hasil wawancara. 
JIPSINDO No. 1, Volume 6, Maret 2019

\section{Hasil Penelitian}

Islamic Boarding School Bina Umat adalah Sekolah Islam Terpadu yang berbasis pesantren modern berdiri diatas tanah wakaf seluas $12.000 \mathrm{~m} 2$ berkedudukan di dusun Setran, Sumberarum, Moyudan, Sleman, Yogyakarta dibawah naungan Yayasan Bina Umat Mulia Yogyakarta yang bergerak dibidang sosial keagamaan.Yayasan Bina Umat Mulia Yogyakarta yang mulanya bergerak dibidang Bimbingan Haji (KBIH Bina Umat) dan pengelolaan zakat (LAZ Bina Umat), tergerak untuk ikut berperan serta dalam proses tarbiyah/pendidikan umat maka didirikan Pondok Pesantren Bina Umat yang bersifat non formal pada tahun 2001.

Visi dan Misi Bina Umat yaitu Mencetak generasi unggul dalam ilmu pengetahuan dan teknologi yang berlandaskan iman dan taqwa (visi). Sedangkan misinya yaitu (1) Menyelenggarakan kegiatan pendidikan yang memadukan antara system pendidikan nasional dan pendidikan pondok modern; (2) Meletakkan dasardasar pendidikan yang menyeluruh dan seimbang dalam aspek afektif, kognitif, dan psikomotorik, dan Aqliyah(fikir), ruhiyyah (rohani), dan jasadiyah. (3) memadukan iptek dan imtaq.

Bina umat mempunyai organisasi siswa Intra sekolah yang sama dengan organisasi di Sekolah yang lainnya namun istilah nya bukan OSIS namun OSB (Organisasi Santri Bina Umat) yang mempunyai tugas dan fungsinya sama dengan OSIS. Pengurus OSB yang ada di Bina Umat adalah semua siswa kelas XI tanpa terkecuali. Sedikit ada perbedaan dengan sekolah yang lainnya bahwa kegiatan OSB dilaksanakan diluar waktu sekolah baik pagi, sore atau malam hari. Hal tersebut dilakukan karena SMA IT Bina Umat merupakan sekolah berbasis pesantren yang mana semua siswa harus tinggal di asramanya serta didampingi ustadz- 
ustadzah yang tinggal diasrama sebagai pembimbing yang biasa dikenal dengan istilah musyrif atau musyrifah. Hasil wawancara dengan pembimbing OSB sebagai berikut:

Pengurus OSB harus mempunyai karakter responsibility atau tanggung jawab yang bagus dalam menjalankan tugas kepengurusan. Namun selain itu karakter-karakter yang lainnya seperti jujur, disiplin, pekerja keras, mandiri, peduli sosial, kerjasama, dan lain-lain itu juga sangat penting harus ada dalam diri anggota pengurus OSB kelak agar kuat dan mampu untuk menjalankan tugas dan problem yang akan dialami kelak ketika kepengurusan. (Wawancara dengan pembimbing OSB, 2018)

Karakter yang harus dimiliki oleh pengurus OSB nantinya sikap tanggung jawab, mampu bekerja sama dengan baik, mental yang kuat, religius karena berada di lingkungan pesantren, dan lain sebagainya. (wawancara dengan wali kelas, 2018)

Karakter yang diharapkan ada dalam diri pengurus OSB sebai berikut, yaitu:

a. Religius

Pengurus OSB diharapkan mampu bersikap patuh dalam menjalankan perintah agama dan menjauhi larangan-Nya, serta mampu bersikap sopan santun terhadap ustadz-ustadzahnya dan kakak kelas, serta menyayangi adik kelasnya. Pengurus OSB tepat waktu dalam menjalankan sholat walaupun terkadang ada beberapa pengurus OSB ke Masjid ketika sudah iqomah, menjalankan amanah kepengurusan dengan baik, tahfidznya sesuai dengan target walaupun ketika waktu setor tidak banyak yang santri atau peserta didik yang setoran, dan selalu berusaha untuk melakukan amalan amalan sunah. (observasi, 2018)

b. Jujur

Pengurus OSB harus mempunyai karakter jujur, yang mana ketika diberi amanah akan bisa menjalankan amanah 
dengan baik. Jujur dalam semua hal baik untuk diri sendiri maupun orang lain.

c. Toleransi

Ketika menjadi pengurus OSB tentunya sesama anggota akan mengalami perbedaan sikap, pendapat, atau perkara lain sehingga terkadang akan mengalami permusuhan antara anggota. Dengan adanya sikap toleransi itu akan meminimalisir permasalahan yang ada dalam kepengurusan.

Ada perubahan dari diri saya setelah menjadi pengurus, sekarang lebih dewasa, lebih bisa memahami temanteman, tidak egois lagi. Selain saya, teman-teman yang lain juga berubah yang awalnya dulu saya kira tidak serius dalam kepengurusan nanti tapi sekarang dia lebih semangat dan sangat bertanggungjawab. (Wawancara dengan NH ketua OSB Akhwat)

Perubahan yang dialami oleh $\mathrm{NH}$ tersebut sangat positif dan penting karena sebagai ketua OSB yang akan selalu mendapat sorotan dari teman-temannya ataupun adik kelasnya.

d. Disiplin

Karakter disiplin sangat dibutuhkan karena salah satu kunci kesuksesan seseorang khususnya pengurus OSB. kedisiplinan ini selaluditerapkan dalam setiap kegiatan seperti sholat berjama'ah, sekolah, piket atau kerja bakti, dan kegiatan yang lainnya.

Sekarang saya lebih disiplin dalam melakukan banyak hal karena kami dijadikan contoh untuk teman-teman yang lain. (wawancara dengan HNR, 2018).

Pemahaman tentang kedisiplinan memang selalu dilakukan karena pengurus OSB sudah tidak bisa seenaknya sendiri dalam artian mereka harus lebih dulu mematuhi aturan yang ada dipondok maupun di sekolah. Mereka akan selalu 
menjadi sorotan dan buah bibir adik kelasnya jika melakukan kesalahan. Namun bukan berarti mereka harus langsung berubah namun bertahap.

e. Kerja keras

Pengurus OSB dalam menjalankan tugas harus dengan kesungguhan hati dan kerja keras sehingga dapat menyelesaikan tugas kepengurusan atau tugas lainnya. Pengurus OSB dalam menjalankan tugasnya dilakukan dengan maksimal didampingi musyrif atau musyrifah yang ada di asrama, seperti divisi keamanan rela tidur paling akhir karena menunggu santri yang lain untuk tidur dan berkeliling pondok untuk memastikan santri yang lain ke kamar masing-masing untuk istirahat. Divisi bahasa yang dengan tekun mencari kosa kata baru untuk diajarkan kepada santri yang lain, divisi taklim yang memantau santri untuk selalu belajar, divisi kesenian yang memfasilitasi buku-buku bacaan untuk refreshing santri, divisi pramuka yang selalu menjalankan kegiatan pramuka berjalan seminggu sekali. Divisi kesehatan dan olah raga yang selalu mengecek kesehatan santri dan memfasilitasi olah raga agar selalu sehat santri.

f. Mandiri

Pengurus OSB harus mempunyai karakter mandiri, yang mana tidak bergantung dengan orang lain dalam menjalankan tugasnya kecuali jika tugas tersebut berkelompok maka harus diselesaikan bersama-sama. Mandiri disini adalah mempunyai sikap mandiri dalam berbagai hal seperti mandiri dalam menjalankan tugas, dan mampun juga menyelesaikan masalah dengan baik. 
g. Demokratis

Karakter ini harus dimiliki dikarenakan masih banyaknya anggota OSB yang mempunyai ego yang tinggi dan keras kepala sehingga menimbulkan persalahan dengan sesama anggota. Diharuskan adanya sebuah forum untuk bisa menyampaikan keluh kesah atau pendapat anggotanya. Awalawal kepengurusan, mereka memiliki ego yang tinggi namun setelah menjadi pengurus ada perubahan yaitu mereka lebih memahami teman dan menghargai pendapat temannya.

h. Bersahabat

Sesama anggota OSB diharapkan mampu bersahabat dengan semua orang, tidak boleh ada pemisah atau sekat antara anggota satu dengan yang lainnya. Berteman atau bersahabat itu harus dilakukan karena manusia adalah makhluksosialyang tidak bisa hidup sendiri tanpa bantuan orang lain begitu pula OSB yang mana harus saling membantu sesama team dan dengan yang lain.

i. Cinta tanah air

Rasa cinta tanah air harus tertanam juga dalam diri semua peserta didik khususnya anggota pengurus OSB sendiri. Untuk menanamkan jiwa cinta tanah air dilakukan dengan adanya kegiatan upacara yang dilakukan 2 minggu sekali, memperingati 17 an, dan kegiatan-kegiatan yang lainnya.

j. Peduli sosial

Kepengurusan OSB dilatih bagaimana kita mau dan mampu peduli dengan temannya yang lain karena kita semua merupakan makhluk sosial yang tidak bisa hidup sendiri dan tentunya membutuhkan orang lain. Sikap peduli sosial itu tidak tumbuh dengan sendirinya namun membutuhkan tahapan dan pembiasaan. 
k. Tanggung jawab

Karakter ini yang sangat dibutuhkan ketika menjadi pengurus OSB, karena tanpa adanya tanggung jawab maka semua kegiatan atau tugas kepengurusan akan berantakan.

Sikap saya dari dulu sampai sekarang sama saja, biasa saja namun untuk sekarang saya lebih tanggung jawab sekarang walaupun terkadang harus lebih mengalah dan sabar (wawancara dengan $\mathrm{AH}$ )

Sikap bertanggungjawab harus adadalam diri seseorang, karena jika sekali seseorang dikasih amanah tidak bertanggungjawab maka orang lain akan sulit untuk mempercayainya lagi. Untuk membentuk karakter tersebut diatas tantunya bukan hal yang mudah karena ada beberapa faktor yang melatarbelakanginya,yaitu

1. Faktor Intern

a. Insting atau Naluri

Setiap individu mempunyai naluri untuk berbuat namun naluri tersebut disertai dengan pemikiran yang matang sehingga membuat munculnya masalah dengan dirinya sendiri ataupun masalah dengan orang lain.

b. Adat atau kebiasaan

Kebiasaan yang sering dilakukan sehingga membuatnya sulit berubah.

c. Kehendak atau kemauan

Keegoisan individu khususnya pengurus OSB sehingga menjadikan sulitnya diajak untuk kerjasama.

d. Keturunan

Karakter dari kecil yang akan terus melekat pada individu pengurus OSB. 


\section{Faktor Ekstern}

Berbagai kegiatan dilakukan untuk mempersiapkan anggota OSB yang berkualitas dengan cara yaitu diadakannya renungan malam, penyampaian visi dan misi calon ketua osis, pertemuan semua calon anggota osis, dan setelah pelantikan diadakannya Up grading serta outbond. Kegiatan renungan malam yang bertujuan untuk melatih rasa kepercayaan diri, saling percaya, kepemimpinan, kerjasama, kerja keras dan kejujuran. Kegiatan penyampaian visi dan misi calon ketua OSB bertujuan untuk menumbuhkan rasa percaya diri, dan keberanian menyampaikan pendapat didepan forum. Perkumpulan kelas 11 bertujuan untuk mengetahui kesanggupan dari santri dalam memilih divisi dalam kepengurusan. Dan up grading bertujuan untuk memberikan arahan tentang organisasi tersebut dan memberikan motivasi, serta outbond yang bertujuan untuk menumbuhkan jiwa pemimpin, kerjasama, kesabaran, dan lain sebagainya.

Metode yang digunakan dalam membentuk karakter calon pengurus OSB yaitu:

1. Metode ceramah

Metode ini dilakukan dalam setiap kegitatan. Dalam metode terkadang disisipin dengan cerita-cerita yang dilakukan oleh pembimbing ataupun wali kelas ketika mengajar, ketika MPK, dan ketika berkumpul dengan pengurus OSB.

Ketika saya mengajar, MPK, dan ketika berkumpul dengan santri saya selalu memberi pemahaman mereka tentang pentingnya akhlak baik terhadap teman, adik kelas, maupun ustadz-ustadzahnya karena itu juga sebagai ladang pahala dan memperoleh ilmu yang berkah. (Wawancara dengan wali kelas XI IPA) 
Marwah Rusydiana

Metode ini biasanya dilakukan jika berada dalam forum yang lebih besar, contohnya ketika berada dikelas. Dalam metode ini guru atau pembimbing yang lebih aktif dan pengurus OSIS mendengarkan dengan seksama. Namun bukan berarti guru yang selalu aktif, terkadang mereka dikasih waktu untuk bercerita tentang kepengurusan khususnya yang sedang dihadapi karena jika santri menghadapi masalah dalam kepengurusan OSB dikhawatirkan berdampak buruk terhadap prestasi akademiknya, selain itu ada yang mudah sakit kepala, tidur ketika dikelas, nilai pelajaran menurun, dan lain sebagainya.

2. Diskusi

Metode ini dilakukan ketika sedang ada kumpul dengan pengurus OSB ataupun ketika mendampingi rapat pengurus OSB. Diskusi dilakukan dalam internal pengurus OSB itu sendiri yang mana diskusi dilakukan untuk memecahkan permasalahan yang sedang dialami atau membuat program yang baru untuk kepengurusan.

Kalau ada masalah dengan anggota divisi biasanya diajak ngobrol, dan cari solusi bareng-bareng. Kalau seandainya belum selesai biasanya minta tolong ke inti ataupun ustadz-ustadzah untuk saling membantu menyelesaikan masalah. (wawancara dengan AHS, 2018)

Setiap ada masalah yang muncul harus diskusikan dan diklarifikasi agar jelas duduk permasalahannya apa terkadang masalah tersebut muncul akibat keegoisan individu masing-masing sehinggu perlu adanya ruang dan waktu untuk lebih memahami antara satu dengan anggota yang lainnya (wawancara dengan pembimbing OSB, 2018)

Metode ini harus dilakukan karena bisa lebih merekatkan antara satu dengan yang lainnya. Jika diskusi 
tidak ada maka pengurus OSIS akan kehilangan arah karena rasa ego masing-masing individu besar sehingga tidak akan ada yang mau mengalah, tidak ada yang mengklarifikasi jika permasalahan tersebut akibat kesalahpahaman, semaunya sendiri, tidak disiplin, dan sering terjadi perselisihan. Permasalahan tersebut tentunya tidak ingin terjadi karena akan merugikan diri sendiri maupun orang lain. Metode didikusi ini bisa dilakukan dalam kelompok kecil mapun kelompok besar. Kelompok kecil terdiri hanya beberapa orang seperti pengurus inti, anggota per devisi, dan pengurus inti gengan ketua-ketua bidang. Ketika membahas program kerja dan evaluasi dalam internal masing-masing maka mereka hanya dalam lingkup kecil.

3. Pemberian tugas (resitasi)

Pengurus OSB diberikan tugas sesuai dengan bagiannya. Seperti bagian ibadah bertanggung jawab terharap pelaksaan ibadah setiap hari, bagian keamanan bertanggung jawab mengamankan asrama, bagian bahasa bertanggung jawab untuk mengawasi Bahasa Arab dan Inggris santri, bagian ta'lim yang bertanggung jawab pelaksaanan muhadhoroh, kegiatan belajar, dan kultum, dan bagian-bagian yang lainnya.

Selain itu anggota divisi ibadah pun membagi tugas masing-masing, ada yang bertugas keliling asrama untuk meminta santri ke masjid, ada yang bertugas mencatat santri yang terlambat ke masjid, ada yang bertugas mengumumkan santri agar segera ke masjid, dan ada yang bertugas ngabsen santri yang ke masjid. Divisi keamanan, ada yang bertugas berkeliling pondok setiap malam, ada 
yang bertugas mengumumkan santri agar segera ke sekolah, pembagian tugas menulis surat untuk perizinan. Divisi bahasa, ada yang bertugas mencari santri yang tidak berbahasa arab ataupun bahasa inggris, ada yang bertugas menulis mufrodad di papan kecil yang ada di tangga,ada yang bertugas mengkoordinir pengumpulan insya', dan lainlain. Divisi kesehatan, ada yang bertugas keliling kalau ada santri yang sakit, mengantar santri ke klinik bina umat, dan mengurus obat. Divisi ta'lim, ada yang bertugas mengumumkan waktu belajar, ada yang bertugas berkeliling pondok agar semua belajar diluar kamar dan tidak ngobrol sama teman atau malahan tidur, kecuali bagi santri yang sedang sakit diperbolehkan untuk berada di kamar dan istirahat. Divisi wirausaha, divisi ini saling membantu dalam menjual barang atau makanan, selain itu ada yang bertugas menerima telfon, menulis yang ditelfon siapa dan waktu penggunaan, dan lain-lain. Begitu pula dengan divisi yang lainnya yang mana mempunyai tugas dan tanggung jawab berbeda-beda.

Sebelum menjadi OSB, ketika mereka kelas 10 dan kelas 11 waktu itu ada kegiatan diluar maka merekalah yang mengantikan tugas menjadi pengurus. Selain itu, mereka diberi waktu seperti magang untuk lebih memahami kepengurusan OSB itu bagaimana agar tidak kaget menjadi pengurus nantinya.

4. Pembiasaan

Pengurus OSB dilatih untuk disiplin, memutuskan untuk mengadakan kegiatan dalam rapat atau dengan cara musyawarah mufakat, dan lain sebagainya. Pembiasan disini adalah pembiasaan yang bagus. Berada dipondok 
adalah membiasakan santri untuk bangun pagi dan melaksakan sholat, membiasakan santri untuk sholat berjama'ah dan tepat waktu, membiasakan santri saling menolong ketika ada teman yang susah atau yang sedang sakit, membiasakan santri untuk memahami antara satu dengan yang lainnya, dan membiasakan santri untuk tidak bisa seenaknya sendiri, maksudnya mempunyai ego yang tinggi yang dikhawatirkan bisamerusak hubungan dengan temannya.

\section{Simpulan}

Calon peserta didik pengurus OSB mempunyai karakter yang berbeda-beda. Walaupun berbeda-beda karakter kepengurusan OSB harus mempunya goal yang sama yaitu menyukseskan kepengurusan. Karakter yang dibentuk dalam menyiapkan calon Pengurus OSB yaitu religius, jujur, toleransi, disiplin, kerja keras, mandiri, demokratis, cinta tanah air, bersahabat, peduli lingkungan, peduli sosial, dan tanggungjawab. Metode yang digunakan dalam membentuk karakter calaon pengurus OSB yaitu: (1) Metode ceramah, Metode ini dilakukan dalam setiap kegiatan yang dilakukan oleh pembimbing ataupun wali kelas; (2) Metode Diskusi, metode ini dilakukan ketika sedang ada kumpul dengan pengurus OSB ataupun ketika mendampingi rapat pengurus OSB; (3) metode Pemberian tugas (resitasi), Pengurus OSB diberikan tugas sesuai dengan bagiannya; dan (4) Metode Pembiasaan, Pengurus OSB dilatih untuk disiplin, memutuskan untuk mengadakan kegiatan dalam rapat atau dengan musyawarah mufakat. 
Marwah Rusydiana

\section{Daftar Pustaka}

Ali Ibrahim Akbar. (2000). Pendidikan Karakter. USA : Harvard University.

Departemen Pendidikan dan Kebudayaan. (1989). Kamus Besar Bahasa Indonesia, Jakarta: Balai Pustaka.

Departemen pendidikan nasional. (2011). Kamus Besar Bahasa Indonesia, Jakarta: Gramedia Pustaka Utama.

Erie Sudewo. (2011). Character Building, Jakarta: Replubika.

F Rudy Dwiwibawa \& Theo Riyanto. (2008). Siap Jadi Pemimpin: Latihan Dasar Kepemimpinan. Yogyakarta: Kanisius.

Heri Gunawan. (2014). Pendidikan Karakter: Konsep dan Implementasi, (Bandung: Alfabeta CV.

Jamal Ma'mur Asmani,. (2012) Buku Panduan Internalisasi Pendidikan Karakter disekolah. Yogyakarta: Diva Press.

Lorens Bagus. (2005). Kamus Filsafat, Jakarta: Gramedia.

Moh. Haitami dan Syamsul Kurniawan. (2012). Filsafat Ilmu. Pontianak: STAIN Pontianak Press, 2012.

Muchlas Samani dan Hariyanto. (2011). Konsep Dan Model Pendidikan Karakter, Bandung: Remaja Rosdakarya.

Nana Syaodih Sukmadinata. (2007). Metode Penelitian Pendidikan, Bandung: PT. Remaja Rosdakarya.

Pupuh Fathurrohman, dkk. (2013). Pengembangan pendidikan Karakter, Bandung: Refika Aditama.

Sugiyono. (2012). Metode Penelitian Pendidikan. Bandung: CV. Alfabeta.

Suharsimi Arikunto. (1986). Dasar-Dasar Evaluasi Pendidikan. Jakarta: PT. Bina Aksara. (2002). Prosedur Penelitian (Suatu Pendekatan Praktek), Jakarta: Rineka Cipta.

Sutrisno Hadi. (2002). Metodologi Research. jilid II. Yogyakarta: Andi Offset. 
Syamsul Kurniawan. (2016). Pendidikan Karakter konsepsi \& Imlimentasinya secara Terpadu di Lingkungan keluarga, Sekolah, Perguruan Tinggi, \& Masyarakat. cet. III Yogyakarta: Ar-Ruzz Media.

Tatang M. Amirin. (1995). Menyusun Rencana Penelitian, Jakarta: Raja Grafika persada.

Tim Penyusun Kamus Pusat Pembinaan dan pengembangan Bahasa, (1989). Kamus Besar Bahasa Indonesia, cet. III. Jakarta: Balai Pustaka.

UU RI Nomor 20 tahun 2003 tentang Sistem Pendidikan Nasional. 2003. Jakarta: Sinar Grafika.

Winarno Surahmat. (1975). Dasar-Dasar Teknik Research, Pengantar Metode Ilmiah, Tarsito.

Zaim Elmubarok. (2008). Membumikan Pendidikan Nilai. Bandung: Alfabeta.

Zubaedi. (2011). Desain Pendidikan Karakter: konsepsi dan alikasinya dalam lembaga pendidika, Jakarta: Gramedia Pustaka Utama. 